\begin{tabular}{|c|c|}
\hline Title & $\begin{array}{l}\text { A n In Situ Electrochemical Quartz Crystal Microbal ance Study of the Dissolution Process of a Gold Electrode in } \\
\text { Perchloric A cid Solution Containing Chloride Ion }\end{array}$ \\
\hline Author(s) & Ye, Shen; Ishibashi, Chikara; Shimazu, Katsuaki; U osaki, Kohei \\
\hline Citation & $\begin{array}{l}\text { Journal of The Electrochemical Society, 145(5), 1614-1623 } \\
\text { https://doi.org/10.1149/1.1838526 }\end{array}$ \\
\hline Issue Date & 1998 \\
\hline Doc URL & http:/hdl.handle.net/2115/50241 \\
\hline Rights & $\begin{array}{l}\text { () The Electrochemical Society, Inc. 1998. All rights reserved. Except as provided under U.S. copyright law, this work } \\
\text { may not be reproduced, resold, distributed, or modified without the express permission of The Electrochemical Society } \\
\text { (ECS). The archival version of this work was published in J. Electrochem. Soc. } 1998 \text { volume 145, issue 5, 1614-1623. }\end{array}$ \\
\hline Type & article \\
\hline File Information & JES145-5_1614-1623.pdf \\
\hline
\end{tabular}

Instructions for use 


\section{An In Situ Electrochemical Quartz Crystal Microbalance Study of the Dissolution Process of a Gold Electrode in Perchloric Acid Solution Containing Chloride Ion}

Shen Ye, Chikara Ishibashi, Katsuaki Shimazu and Kohei Uosaki

J. Electrochem. Soc. 1998, Volume 145, Issue 5, Pages 1614-1623.

doi: $10.1149 / 1.1838526$

\footnotetext{
Email alerting Receive free email alerts when new articles cite this article - sign up service in the box at the top right corner of the article or click here
}

To subscribe to Journal of The Electrochemical Society go to: http://jes.ecsdl.org/subscriptions

(C) 1998 ECS - The Electrochemical Society 
ic Materials, Elsevier, Amsterdam (1995).

3. K. M. Abraham, in Applications of Electroactive Polymers: Highly Conductive Polymer Electrolytes, B. Scrosati, Editor, Chap. 3, p. 75, Chapman and Hall, London (1993).

4. C. J. Brinker and G. W. Scherer, Sol-Gel Science, Academic Press, San Diego, CA (1990).

5. A. Agrawal, J. P. Cronin, and R. Zhang, Sol. Energy Mater. Sol. Cells, 31, 9 (1993).

6. P. Judeinstein and C. Sanchez, J. Mater. Chem., 6, 511 (1996).

7. U. Schubert, N. Hüsing, and A. Lorenz, Chem. Mater., 7, 2010 (1995).

8. M. A. Macêdo and M. A. Aegerter, J. Sol-Gel Sci. Technol., 2, 667 (1994)

9. C. O. Avellaneda, M. A. Macêdo, A. O. Florentino, and M. A. Aegerter, Proc. SPIE, 2255, 38 (1994).

10. D. Kéomany, J.-P. Petit, and D. Deroo, Sol. Energy Mater. Sol. Cells, 36, 397 (1995).

11. U. Lavrenčič Stangar, B. Orel, I. Grabec, B. Ogorevc, and K. Kalcher, Sol. Energy Mater. Sol. Cells, 31, 171 (1993).

12. U. Lavrenčič Stangar, U. Opara, and B. Orel, J. Sol-Gel Sci. Technol., 8, 751 (1997).

13. B. Orel, U. Lavrenčič Stangar, and K. Kalcher, J. Electrochem. Soc., 141, L127 (1994).

14. B. Orel, U. Lavrenčič Stangar, U. Opara, M. Gaberšček, and K. Kalcher, J. Mater. Chem., 5, 617 (1995).

15. U. Opara, B. Orel, S. Hočevar, and I. Muševič, J, Electrochem. Soc., 144, 3398 (1997)

16. A. Surca, B. Orel, B. Pihlar, and P. Bukovec, J. Electroanal. Chem., 408, 83 (1996).

17. F. Svegl, B. Orel, M. G. Hutchins, and K. Kalcher, $J$. Electrochem. Soc., 143, 1532 (1996).

18. F. Svegl, B. Orel, and M. G. Hutchins, J. Electroanal. Chem., 418, 53 (1996).

19. R. D. Rauh and S. F. Cogan, Solid State Ionics, 28-30, 1707 (1988).

20. C. G. Granqvist, Handbook of Electrochromic Materials, Chap. 17, p. 285, Elsevier, Amsterdam (1995), and references cited therein

21. A. Talledo, A. M. Anderson, and C. G. Granqvist, $J$. Mater. Res., 5, 1253 (1990).

22. S. F. Cogan, R. D. Rauh, N. M. Nguyen, T. D. Plante, and
J. D. Westwood, J. Electrochem. Soc., 140, 112 (1993).

23. G. Larramona and C. Gutiérrez, J. Electrochem. Soc. 136, 2171 (1989).

24. R. C. Faria and L.-O. de S. Bulhões, J. Electrochem Soc., 141, L29 (1994)

25. D. C. Bradley, B. N. Chakravarti, and W. Wardlaw, J. Am. Chem. Soc., 7, 2381 (1956).

26. M. Maček, B. Orel, and U. Opara Krašovec, J. Electrochem. Soc., 144, 3002 (1997).

27. T. Kudo, Nature, 312, 537 (1984).

28. R. Nass, E. Arpac, W. Glaubitt, and H. Schmidt, J. NonCryst. Solids, 121, 370 (1990).

29. V. Bhide, E. Husson, and M. Gasperin, Mater. Res Bull., 15, 1339 (1980).

30. E. Husson, Y. Repelin, N. Q. Dao, and H. Brusset, Mater. Res. Bull., 12, 1199 (1977).

31. T. Ikeya and M. Senna, J. Non-Cryst. Solids, 105, 243 (1988).

32. X-Ray Powder Diffraction File, JCPDS-ICPD, PDF No. 24-0072D.

33. B. Orel, M. Maček, F. Švegl, and K. Kalcher, Thin Solid Films, 246, 131 (1994).

34. S. Onari, T. Arai, and K. Kudo, Phys. Rev. B, 16, 1717 (1977).

35. V. C. Farmer, in The Infrared Spectra of Minerals: The Anhydrous Oxide Minerals, V. C. Farmer, Editor, Mineralogical Society, London (1974).

36. A. S. Barker, Jr., J. A. Ditzenberger, and H. J. Guggenheim, Phys. Rev., 175, 1180 (1968).

37. B. Orel, U. Opara Krašovec, U. Lavrenčič Štangar, and P. Judeinstein, Sol-Gel Sci. Technol., 11, 1 (1998).

38. F. Decker, S. Passerini, R. Pileggi, and B. Scrosati, Electrochim. Acta, 37, 1033 (1992).

39. N. Özer, M. D. Rubin, and C. M. Lampert, Sol. Energy Mater. Sol. Cells, 40, 285 (1996).

40. N. Özer, T. Barreto, T. Buyuklimanli, and C. M. Lampert, Sol. Energy Mater. Sol. Cells, 36, 433 (1995).

41. G. Campet, S. J. Wen, S. D. Han, M. C. R. Shastry, J. Portier, C. Guizard, L. Cot, Y. Xu, and J. Salardenne, Mater. Sci. Eng. B, 18, $201(1993)$

42. T. Maruyama and T. Kanagawa, J. Electrochem. Soc., 143, $1675(1996)$

43. B. Orel, M. Maček, J. Grdadolnik, and T. Meden, $J$ Solid State Electrochem., In press (1998).

\title{
An In Situ Electrochemical Quartz Crystal Microbalance Study of the Dissolution Process of a Gold Electrode in Perchloric Acid Solution Containing Chloride lon
}

\author{
Shen $\mathrm{Ye}^{*}$ Chikara Ishibashi, Katsuaki Shimazu, ${ }^{*, a}$ and Kohei Uosaki ${ }^{*}$ \\ Physical Chemistry Laboratory, Division of Chemistry, Graduate School of Science, and ${ }^{a}$ Division of Material Science, \\ Graduate School of Environmental Earth Science, Hokkaido University, Sapporo 060, Japan
}

\section{ABSTRACT}

The anodic dissolution process of a $\mathrm{Au}(111)$ oriented electrode in $\mathrm{HClO}_{4}$ solution containing various concentrations of chloride ion was investigated using an electrochemical quartz crystal microbalance (EQCM) under potential sweep and potentiostatic conditions. The in situ EQCM results clearly demonstrated that gold dissolves through a 3e oxidation process in the anodic potential region. No evidence for the $1 \mathrm{e}^{-}$dissolution was obtained in the present study.

\section{Introduction}

Gold is known to have an excellent chemical stability. However, it becomes unstable and dissolves in the positive potential region, ${ }^{1-3}$ especially in solutions containing chloride ion. ${ }^{4-14}$ This property is particularly important in the modern electronic industry for designing and manufacturing certain thin films and integrated circuits. Heumann and Panesar potentiostatically investigated the anodic behavior of a gold electrode in sulfuric acid solution containing chloride ion $\left(\mathrm{Cl}^{-}\right)$of various concentrations. ${ }^{4}$ They proposed that both the $1 \mathrm{e}^{-}$and $3 \mathrm{e}^{-}$oxidation reactions were involved in

* Electrochemical Society Active Member. the gold dissolution reaction in the anodic potential region as expressed by reactions 1 and 2 , respectively

$$
\begin{array}{ll}
\mathrm{Au}+4 \mathrm{Cl}^{-} \rightarrow \mathrm{AuCl}_{4}^{-}+3 \mathrm{e}^{-} & E^{0}=1.00 \mathrm{~V} \\
\mathrm{Au}+2 \mathrm{Cl}^{-} \rightarrow \mathrm{AuCl}_{2}^{-}+1 \mathrm{e}^{-} & E^{0}=1.15 \mathrm{~V}
\end{array}
$$

Gaur and Schmid studied the gold dissolution in the potential region of $+1.0 \sim+1.2 \mathrm{~V}$ (vs. SCE) in $0.1 \mathrm{M} \mathrm{HClO}_{4}$ containing $0.2-10 \mathrm{mM} \mathrm{KCl}{ }^{5}$ They suggested that gold dissolution and oxide formation are competitive reactions in the positive potential region and gold is dissolved as $\mathrm{AuCl}_{4}^{-}$(reaction 1) only at an "oxygen-free" site on the gold electrode surface. Cadle and Bruckenstein investigat- 
ed the anodic behavior of the gold electrode in $0.2 \mathrm{M}$ $\mathrm{H}_{2} \mathrm{SO}_{4}$ containing a trace amount of $\mathrm{Cl}^{-}$by using a rotating ring-disk electrode and found that a cathodic current was observed at the ring electrode $\left(E_{\text {ring }}=0 \mathrm{~V}\right.$ vs. SCE) as soon as the anodic current on the gold disk electrode started to flow around $+1.1 \mathrm{~V}$ (vs. SCE) ${ }^{6}$ They proposed that the gold electrode was dissolved as Au(III) species (reaction 1). Frankenthal et al. reported that gold is dissolved as $\mathrm{Au}(\mathrm{I})$ (reaction 2 ) at less positive potentials $(<+0.8 \mathrm{~V}$ vs. SCE) with a reaction order of $\mathrm{Cl}^{-}$of 1.9 and as $\mathrm{Au}(\mathrm{III})$ (reaction 1) in a more positive potential region $(<+1.1 \mathrm{~V}$ vs. SCE) with a diffusion-limited anodic current. ${ }^{7,8}$ Horikoshi et al. investigated the corrosion behavior of gold in $0.2 \mathrm{M} \mathrm{H}_{2} \mathrm{SO}_{4}$ solution containing $\mathrm{Cl}^{-}$using coulometry and atomic absorption spectroscopy. ${ }^{9}$ They concluded that the $1 \mathrm{e}^{-}$dissolution process (reaction 2 ) occurred at potentials more negative than $+1.1 \mathrm{~V}$ (vs. SCE) and the $3 \mathrm{e}^{-}$dissolution process (reaction 1) occurred at potentials more positive than +1.1 V. Lovrecek et al. studied the anodic dissolution and passivation behaviors of gold electrodes in neutral and acidic sulfate solutions, with and without $\mathrm{Cl}^{-}$, using a rotating disk electrode. ${ }^{10}$ They confirmed a diffusion-activation control of the dissolution process and suggested that $\mathrm{AuCl}_{4}^{-}$was the final dissolution product. Diaz et al. investigated gold dissolution and deposition on a gold-deposited $\mathrm{Pt}$ rotating disk electrode in solutions with different $\mathrm{Au}(\mathrm{I}) / \mathrm{Au}(\mathrm{III})$ molar ratios, $\mathrm{pH}$ values, and $\mathrm{Cl}^{-}$ concentrations. ${ }^{11}$ Based on the kinetics and thermodynamics analyses of the current-potential curves, they proposed that gold dissolved exclusively as $\mathrm{AuCl}_{2}^{-}$at $0.8 \mathrm{~V}$ (vs. SCE) and as $\mathrm{AuCl}_{4}^{-}$at more positive potentials. By using in situ surface-enhanced Raman spectroscopy (SERS) measurements, Loo found the formation of $\mathrm{AuCl}_{2}^{-}$and $\mathrm{AuCl}_{4}^{-}$ species on a gold electrode surface in $0.1 \mathrm{M} \mathrm{KCl}^{2}$ solution in a potential region more negative and more positive than $+0.9 \mathrm{~V}$ (vs. SCE), respectively. ${ }^{12}$

Recently, the dissolution process on a gold single-crystal surface in a solution containing trace amounts of $\mathrm{Cl}^{-}$has been monitored by in situ scanning tunneling microscopy (STM) ${ }^{13-14}$ Terraces of the gold substrate in a $\mathrm{Cl}^{-}$-containing solution seem to be smoother than those in a $\mathrm{Cl}^{-}$-free solution after the formation and reduction of gold oxide. The faster surface diffusion rate of gold atoms in a $\mathrm{Cl}^{-}$containing solution was proposed. ${ }^{13,14}$

A number of issues concerning the anodic behavior of gold electrodes are still unclear. The quantitative analyses of product during the potentiostatic polarization measurements were usually carried out after a prolonged electrolysis because of the low sensitivity of the analysis techniques. This may cause a significant change in the surface state on the electrode and introduce larger errors in the quantitative analyses, especially in the case of a lower concentration of the product. Furthermore, since most of the studies were carried out on a polycrystalline gold electrode surface, it is impossible to discuss the mechanism of the dissolution process of the gold electrode on an atomic level.

In the present study, an electrochemical quartz crystal microbalance (EQCM) was employed to investigate the electrochemical dissolution process of a $\mathrm{Au}(111)$-orientated electrode surface in perchloric acid $\left(\mathrm{HClO}_{4}\right)$ solution containing $\mathrm{Cl}^{-}$. EQCM can detect in situ mass changes at the electrode/electrolyte interface on a nanogram level with a time resolution of $1 \mathrm{~s}$ or better. ${ }^{15-18}$ It is clearly demonstrated that gold dissolves through a $3 \mathrm{e}^{-}$oxidation process (reaction 1) over a very wide potential region. No evidence for the $1 \mathrm{e}^{-}$dissolution process (reaction 2) was found in the present study.

\section{Experimental}

EQCM measurements were carried out at a $\mathrm{Au}(111)$-oriented electrode prepared by vacuum evaporation of $3 \mathrm{~nm}$ titanium followed by $150 \mathrm{~nm}$ gold onto a $5 \mathrm{MHz}$ AT-cut quartz crystal plate which was held at $300^{\circ} \mathrm{C}$ with an evaporation rate of ca. $0.5 \mathrm{~nm} / \mathrm{s}$. The formation of the highly ordered $\mathrm{Au}(111)$ phase with a long-range terrace-step structure by these procedures has been reported before ${ }^{19,20}$ and was confirmed by STM in this study. A gold bead electrode prepared by melting one end of a gold wire $10.8 \mathrm{~mm}$ diam) was also used for electrochemical characterization. ${ }^{21}$ A standard surface treatment procedure including annealing with a gas $/ \mathrm{O}_{2}$ flame and quenching in pure water was used to obtain reproducible surface states of the substrate. In order to investigate the gold dissolution process with the same surface state, only the first potential sweep was used for the EQCM measurement after the pretreatment.

Electrolyte solutions were prepared using Suprapure grade $\mathrm{HClO}_{4}$ and $\mathrm{NaCl}$ (Wako Pure Chemicals) and Milli$\mathrm{Q}$ water. The concentration of $\mathrm{Cl}^{-}$was adjusted by adding $1.0 \mathrm{M} \mathrm{NaCl}$ stock solution into $0.1 \mathrm{M} \mathrm{HClO}_{4}$ solution.

The electrode potential was controlled by a potentiostat (Hokuto Denko, HA-151) and external potential modulation was provided by a function generator (Hokuto Denko, HB-111). A quasi-reversible hydrogen electrode and a platinum wire $(0.5 \mathrm{~mm}$ diam) were used as the reference and counter electrodes, respectively. All the potentials in this paper are presented with respect to the reversible hydrogen electrode ( $\mathrm{RHE}$ ).

The resonant frequency of the quartz crystal electrode, which was oscillated by a homemade oscillation circuit, was simultaneously monitored by a frequency counter (Hewlett Packard, HP53131A) controlled by a personal computer (NEC PC9821cb2) through a GPIB interface with respect to electrode potential and current. The frequency stability of the EQCM system was better than $0.1 \mathrm{~Hz}$ for a sampling gate time of $0.1 \mathrm{~s}$. Details of the EQCM system used in this study were similar to those previously described. ${ }^{18,22}$ The mass change $(\Delta m)$ was estimated from the resonant frequency change $(\Delta f)$ using the Sauerbrey equation ${ }^{15-18}$

$$
\Delta m=-k \times \Delta f
$$

where $k$ is the mass sensitivity of the $5 \mathrm{MHz}$ AT-cut quartz crystal. The value of $k$ was calibrated by the deposition reactions of silver and lead and was $19.3 \mathrm{ng} / \mathrm{Hz} \mathrm{cm}^{2}{ }^{22}$

All the measurements were carried out after the solution was deaerated by passing purified $\mathrm{N}_{2}$ gas through the solution for at least $20 \mathrm{~min}$.

\section{Results and Discussion}

Electrochemical characterization.--Figure 1 shows cyclic voltammograms (CVs) of a gold bead electrode obtained in $0.1 \mathrm{M} \mathrm{HClO}_{4}$ solution with a $\mathrm{Cl}^{-}$concentration of (a) 0 , (b) 0.01 , (c) 0.1 , (d) 1 , (e) 10 , and (f) $100 \mathrm{mM}$ in the potential region of $0 \sim+1.7 \mathrm{~V}$

A broad anodic wave with a peak at $+1.32 \mathrm{~V}$ in the positive potential sweep and a cathodic peak at $+1.17 \mathrm{~V}$ in the negative potential sweep, corresponding to the formation and reduction of oxide on the gold electrode surface, respectively, were observed in $0.1 \mathrm{M} \mathrm{HClO}_{4}$ solution without $\mathrm{Cl}^{-}$(Fig. 1a). An anodic peak with a small positive shift to $+1.38 \mathrm{~V}$ was found in $0.1 \mathrm{M} \mathrm{HClO}_{4}$ solution containing $0.01 \mathrm{mM} \mathrm{Cl}^{-}$(Fig. 1b). The anodic peak was further shifted to $+1.49 \mathrm{~V}$ with a larger peak current as the $\mathrm{Cl}^{-}$concentration was increased to $0.1 \mathrm{mM}$ (Fig. 1c). Cadle and Bruckenstein reported a similar positive shift of the anodic peak in $0.2 \mathrm{M} \mathrm{H}_{2} \mathrm{SO}_{4}$ solution containing a trace amount of $\mathrm{Cl}^{-}$. This peak shift should be related to the adsorption of $\mathrm{Cl}$ on the gold electrode surface which inhibits the formation of gold oxide in this potential region. ${ }^{6,23-26}$ No change was found in the cathodic peak at $+1.17 \mathrm{~V}$ (Fig. 1a-c). As the $\mathrm{Cl}^{-}$concentration became greater than $1 \mathrm{mM}$, the $\mathrm{CVs}$ drastically changed (Fig. 1d-f). The anodic peak around $+1.4 \mathrm{~V}$ increased with the increase in $\mathrm{Cl}^{-}$concentration. A second anodic peak or shoulder was observed around $+1.5 \mathrm{~V}$. The anodic current rapidly decreased as the potential became more positive. In addition to the cathodic peak at $+1.17 \mathrm{~V}$, which was attributed to the reduction of oxide on a gold surface, a new cathodic peak was observed around $+1.0 \mathrm{~V}$ in the negative potential sweep. The higher the $\mathrm{Cl}^{-}$concentration, the smaller the cathodic peak at $+1.17 \mathrm{~V}$ and the larger the new cathodic peak. When the $\mathrm{Cl}^{-}$concentration became higher than $100 \mathrm{mM}$, the cathodic peak at $+1.17 \mathrm{~V}$ disappeared and an anodic peak was 

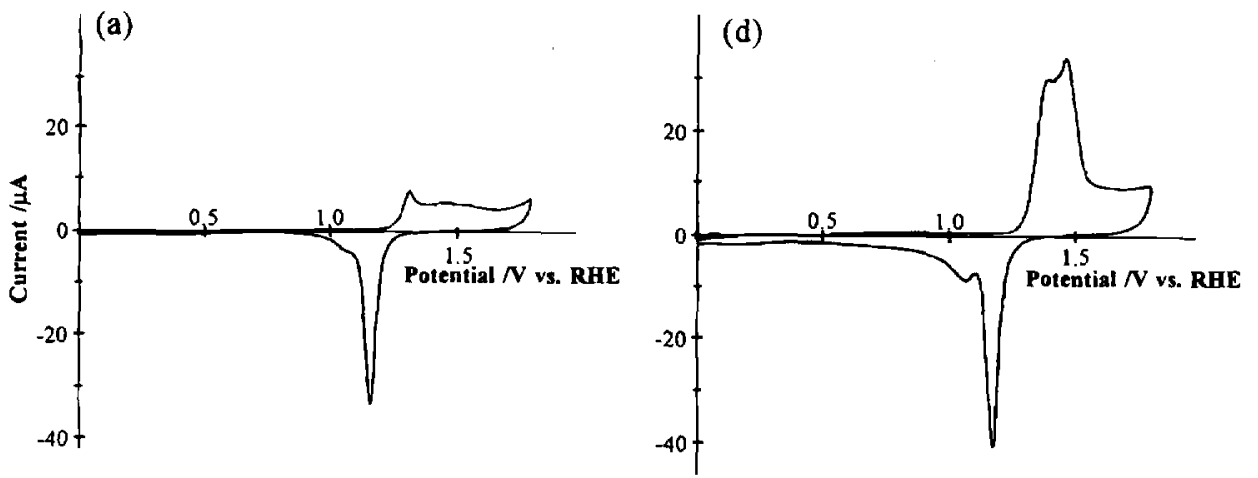

Fig. 1. The CVs of a gold electrode obtained in $0.1 \mathrm{M} \mathrm{HClO}_{4}$ solution containing $\mathrm{Cl}^{-}$at a concentration of (a) $0,(b) 0.01,(c)$ 0.1 , (d) 1 , (e) 10 , and (f) 100 $\mathrm{mM}$ in the potential region between 0 and $+1.7 \mathrm{~V}$. Sweep rate $50 \mathrm{mV} / \mathrm{s}$.
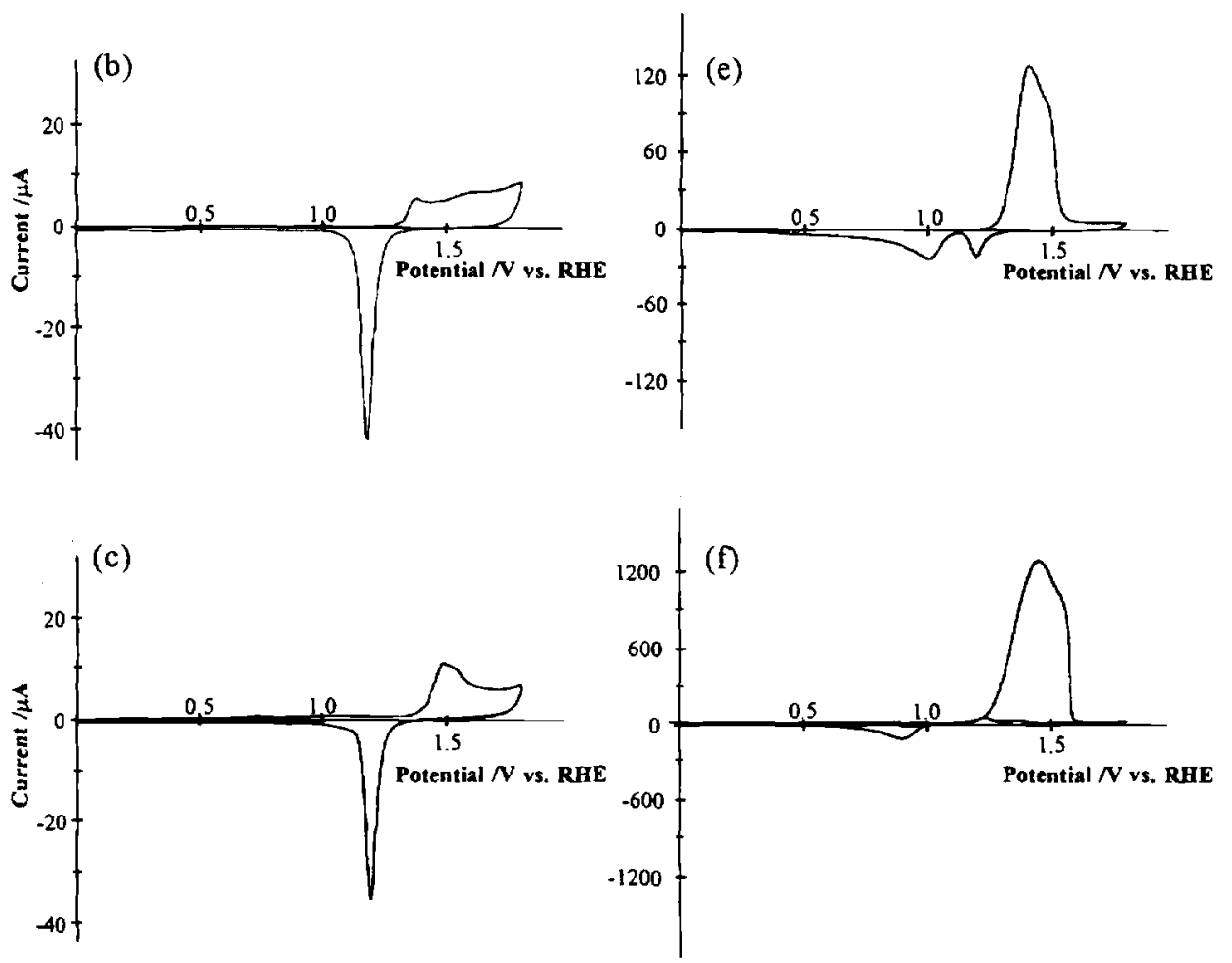

observed at $+1.25 \mathrm{~V}$ (Fig. 1f), showing that an anodic reaction in addition to the reduction of surface oxide took place in this potential region.

Figure 2 shows the electric charges passed in the anodic and cathodic peaks as a function of the $\mathrm{Cl}^{-}$concentration. Both the anodic and cathodic charges were almost constant

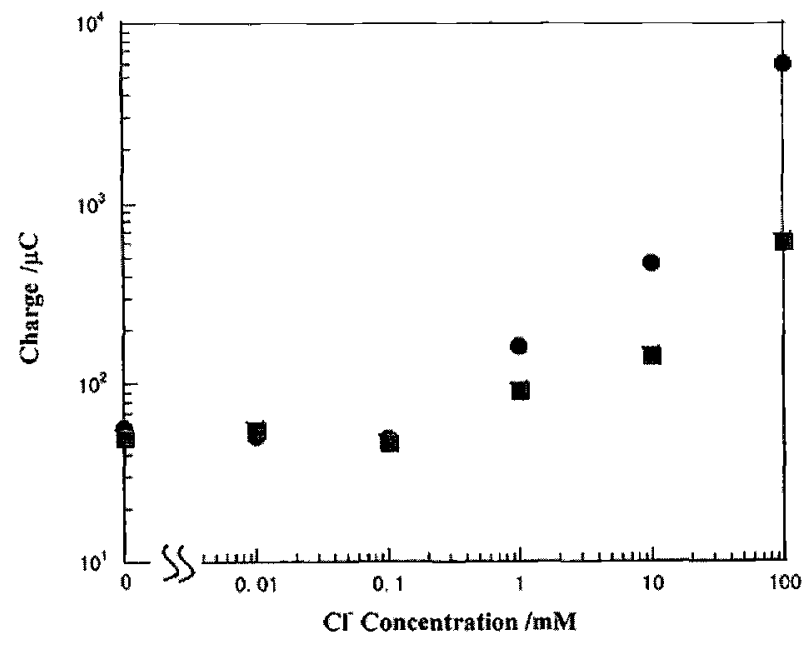

Fig. 2. The anodic $(0)$ and cathodic $(\square)$ charges as a function of the $\mathrm{Cl}^{-}$concentration obtained from the results shown in Fig. 1. as long as the $\mathrm{Cl}^{-}$concentration was lower than $0.1 \mathrm{mM}$ but quickly increased as the $\mathrm{Cl}$ " concentration became greater than $1 \mathrm{mM}$, suggesting new reactions, different from the oxide formation/reduction reactions, took place on the gold electrode. The cathodic charge was always smaller than the anodic charge for a given $\mathrm{Cl}^{-}$concentration.

EQCM characterization with potential sweep in $0.1 \mathrm{M}$ $\mathrm{HClO}_{4}$ with $\mathrm{Cl}^{-}$. - Figure 3 shows the potential dependence of the current (-) and the mass change (- - - ) in the potential region between +0.8 and $+1.7 \mathrm{~V}$ in $0.1 \mathrm{M} \mathrm{HClO}_{4}$ solution with (a) 0 and (b) $1 \mathrm{mM} \mathrm{Cl}^{-}$at a gold electrode which was prepared on a $5 \mathrm{MHz}$ AT-cut quartz crystal plate (sweep rate $50 \mathrm{mV} / \mathrm{s}$ ). A sharp anodic peak at $+1.58 \mathrm{~V}$ and a small peak at $+1.40 \mathrm{~V}$ were observed. The shape of the $\mathrm{CV}$ is similar to those observed on the $\mathrm{Au}(111)$ electrode in $\mathrm{HClO}_{4}$ solution, ${ }^{27,28}$ showing a well-defined $\mathrm{Au}(111)$ surface was exposed in the present experiment. The surface mass of the gold electrode started to increase as the anodic current started to flow and became constant at $+1.7 \mathrm{~V}$. A mass increase of ca. $30 \mathrm{ng}$ was observed between +1.2 and $+1.7 \mathrm{~V}$ in the positive potential sweep (Fig. $3 \mathrm{a}$ ). In the negative potential sweep, the surface mass started to decrease as soon as the cathodic current started to flow at $+1.2 \mathrm{~V}$ and returned to its initial value at $+1.1 \mathrm{~V}$. The reversible potential dependence of the current and the mass changes should be associated with the formation and reduction of gold oxide $\mathrm{de}^{27-32}$

$$
\mathrm{Au}+\mathrm{H}_{2} \mathrm{O} \leftrightarrow \mathrm{AuOH}+\mathrm{H}^{+}+\mathrm{e}^{-}
$$




$$
\mathrm{AuOH} \leftrightarrow \mathrm{AuO}+\mathrm{H}^{+}+\mathrm{e}^{-}
$$

In $0.1 \mathrm{M} \mathrm{HClO}_{4}$ solution containing $1 \mathrm{mM} \mathrm{Cl}^{-}$(Fig. $3 \mathrm{~b}$ ), the surface mass of the gold electrode started to decrease as soon as the anodic current started to flow at $+1.25 \mathrm{~V}$. The mass decrease became small after the second anodic peak at $+1.53 \mathrm{~V}$ and the surface mass became nearly constant around $+1.6 \mathrm{~V}$ where the anodic current quickly decreased. The mass decreased by ca. $300 \mathrm{ng}$ during the potential sweep from +0.8 to $+1.7 \mathrm{~V}$. In the negative potential sweep, the surface mass remained constant as long as the potential was more positive than $+1.3 \mathrm{~V}$ where the cathodic current started to flow and started to decrease further with the appearance of the first cathodic peak at $+1.2 \mathrm{~V}$. The surface mass continued to decrease until $+1.14 \mathrm{~V}$ where a current minimum between the first and the second anodic peaks was observed. The surface mass started to increase as the potential became more negative than this potential. The mass did not return to the original value at $+0.8 \mathrm{~V}$ and $\mathrm{a}$ net mass loss of ca. $200 \mathrm{ng}$ was observed after one potential cycle to $+1.7 \mathrm{~V}$. This behavior is very different from the result in $\mathrm{Cl}^{-}$-free $\mathrm{HClO}_{4}$ solution (Fig. 3a) where no net mass change was observed after a potential cycle. Thus, it is clear that gold was dissolved during a potential cycling in $\mathrm{Cl}^{\prime \prime}$-containing solution.

The CV shown in Fig. $3 \mathrm{~b}$ can be divided into several regions based on the potential dependence of the current and the mass change, i.e., region I $(<+1.25 \mathrm{~V})$, II $(+1.25$ to $+1.45 \mathrm{~V})$, and III $(+1.45$ to $+1.7 \mathrm{~V})$ for the positive sweep, region IV $(+1.7$ to $+1.3 \mathrm{~V}), \mathrm{V}(+1.3$ to $+1.15 \mathrm{~V})$, and VI $(<+1.15 \mathrm{~V})$ for the negative sweep. No anodic current flowed and no mass change was observed in region $I$. Regions II and III corresponded to the potential region of the first anodic peak at $+1.4 \mathrm{~V}$ and the second peak at $+1.53 \mathrm{~V}$, respectively, in the positive potential sweep. The gold electrode is dissolved in region II and started to passivate in region III. Neither a current nor mass change was

(a)

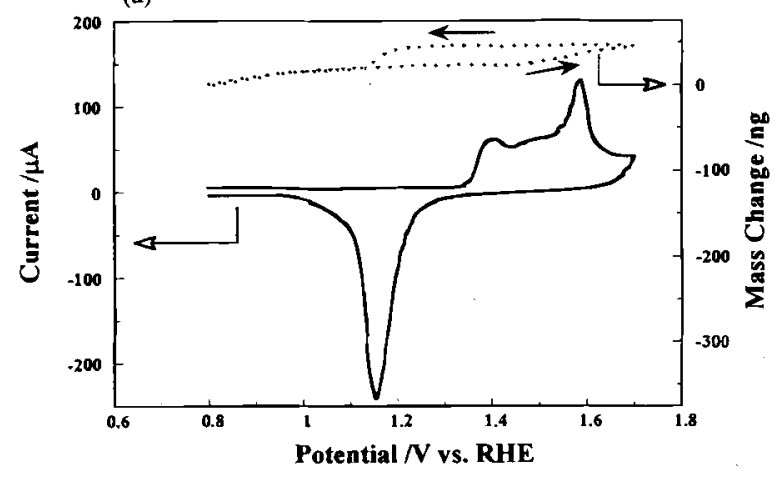

(b)

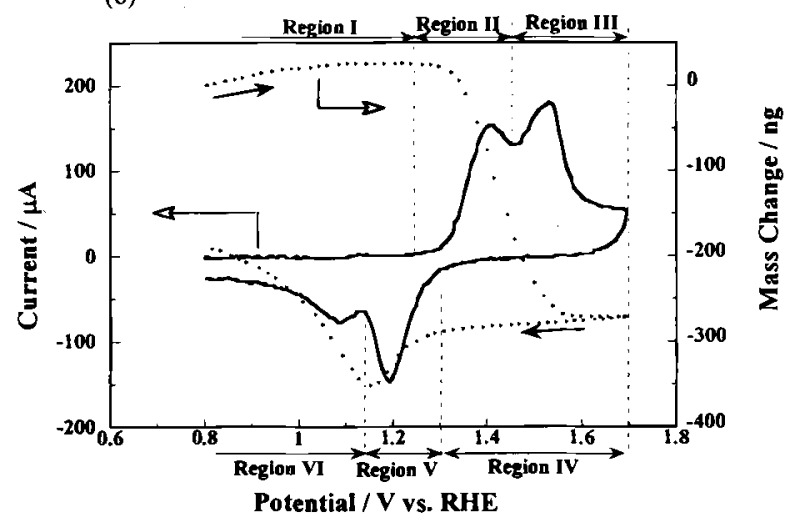

Fig. 3. The potential dependence of current $(-)$ and mass changes $(--)$ in the potential region between +0.8 and $+1.7 \mathrm{~V}$ in $0.1 \mathrm{M} \mathrm{HClO}_{4}$ solution containing (a) 0 and (b) $1 \mathrm{mM} \mathrm{Cl}$. Scan rate $50 \mathrm{mV} / \mathrm{s}$. observed in region IV. Regions V and VI included the first cathodic peak at $+1.17 \mathrm{~V}$ and the second cathodic peak around $+1.0 \mathrm{~V}$, respectively, in the negative potential sweep. It should be mentioned here that this potential division (Fig. $3 \mathrm{~b}$ ) is only an approximate manner and changed with concentration of $\mathrm{Cl}^{-}$and sweep rate. A more precise division can be achieved by a complete deconvolution of these peaks observed in the CV.

Sweep rate dependence.-Figure 4 shows the potential dependence of the current $(-)$ and the mass change (- - - ) in $0.1 \mathrm{M} \mathrm{HClO}_{4}$ solution containing $1 \mathrm{mM} \mathrm{Cl}^{-}$as the sweep rate was reduced to (a) 20 , (b) 10 , and (c) $5 \mathrm{mV} / \mathrm{s}$. The currents were divided by the sweep rate $\left(i v^{-1}\right.$, i.e., capacitance) for normalization. As the sweep rate became lower, anodic and cathodic peaks shifted slightly in the more negative and positive directions, respectively, and the relative height of the first anodic peak around $+1.3 \mathrm{~V}$ became larger than that of the second one around $+1.5 \mathrm{~V}$. The lower the sweep rate, the larger the capacitance of both the anodic and cathodic peaks, and the larger the mass change.

Effect of positive potential limit.-Figure 5 shows the potential dependence of current (top) and the mass change (bottom) observed during a single potential cycle between $+1.0 \mathrm{~V}$ and various positive potential limits in $0.1 \mathrm{M}$ $\mathrm{HClO}_{4}$ solution containing $1 \mathrm{mM} \mathrm{Cl}^{-}$. No significant change of current and mass were observed in the potential sweep between +1.0 and $+1.3 \mathrm{~V}(-)$. As the potential sweep was extended to $+1.45 \mathrm{~V}$ in region II $(\mathrm{O})$, a mass decrease corresponding to the anodic current in the $\mathrm{CV}$ was observed in the potential region between +1.35 and $+1.45 \mathrm{~V}$ in the both positive and negative sweeps. This mass decrease is due to the gold dissolution as already described. Only one cathodic peak was found at $+1.09 \mathrm{~V}$ (region VI) and the surface mass started to increase corresponding to this cathodic peak. When the positive potential limit was extended to $+1.6 \mathrm{~V}$ in region III $(\bullet)$, the mass loss quickly decreased and the surface mass became nearly constant after the anodic peak at $+1.53 \mathrm{~V}$ in the positive sweep. In the subsequent negative sweep, neither a current nor mass change was found until $+1.32 \mathrm{~V}$ (region IV) and two cathodic peaks were observed in the more negative potential region, $+1.22 \mathrm{~V}$ (region $\mathrm{V}$ ) and $+1.08 \mathrm{~V}$ (region VI), respectively. Since only the first cathodic peak around $+1.22 \mathrm{~V}$ was observed in a $\mathrm{Cl}^{-}$-free solution (Fig, 3a) and the second cathodic peak around $+1.08 \mathrm{~V}$ became larger with the increase in $\mathrm{Cl}^{-}$concentration in $\mathrm{Cl}^{-}$-containing solution (Fig. 1), the cathodic peak at $+1.08 \mathrm{~V}$ should be associated with the reduction process of the Au complexes that were produced during the dissolution that took place in region II and no surface oxide was formed in region II.

Effect of negative potential limit.-Figure 6 shows the potential dependence of current (top) and mass change (bottom) recorded during a single potential cycle between $+1.7 \mathrm{~V}$ and various negative potential limits in $0.1 \mathrm{M} \mathrm{HClO}_{4}$ solution containing $1 \mathrm{mM} \mathrm{Cl}^{-}$. The gold electrode was in a passivated state at this potential before the potential scan with a negligible anodic current. When the potential was swept between +1.7 and $+1.3 \mathrm{~V}$, neither a current nor mass change was observed during both the negative and positive sweeps $(-$. When the potential became more negative than $+1.3 \mathrm{~V}$ (region $\mathrm{V}$ ), the surface mass started to decrease in the negative sweep corresponding to the flow of cathodic current $(O)$. When the potential sweep was reversed to the positive direction, the mass continuously decreased corresponding to two anodic peaks in regions II and III $(O)$. When the potential was swept into region VI $(0)$, the surface mass, however, changed and increased as soon as the second cathodic peak started to flow from $+1.15 \mathrm{~V}$, suggesting that the dissolved gold species in solution was reduced on the electrode surface in the second cathodic peak at $+1.08 \mathrm{~V}$ as already described. When the potential sweep was reversed to the positive direction at $+1.0 \mathrm{~V}$, the mass became constant until $+1.3 \mathrm{~V}$ and then started to 
decrease again in regions II and III ( $)$. The present results of the dependence of the negative potential limit (Fig. 6) are in good agreement with those of the dependence of the positive potential limit shown in Fig. 5 .

Quantitative analysis.-Figure 7 shows the mass change on a gold electrode as a function of electric charge passed in Fig. 3b. The respective potential regions as described above are also shown in the same figure. The mass change per mole-equivalent electron (mpe) can be calculated from the slope of the curve. As mentioned in the Introduction, the $3 \mathrm{e}^{-}$and $1 \mathrm{e}^{-}$dissolution processes have been proposed for the dissolution process of a gold electrode in acidic solution containing $\mathrm{Cl}^{-}$. ${ }^{4-12}$ The mpe expected for the $3 \mathrm{e}^{-}$ (reaction 1) and $1 \mathrm{e}^{-}$(reaction 2) processes are 65.7 and $197.0 \mathrm{~g} / \mathrm{mol}-\mathrm{e}$, respectively. The potential-dependent mpe in the respective regions shown in Fig. 7 were calculated and discussed in detail as follows

(a)

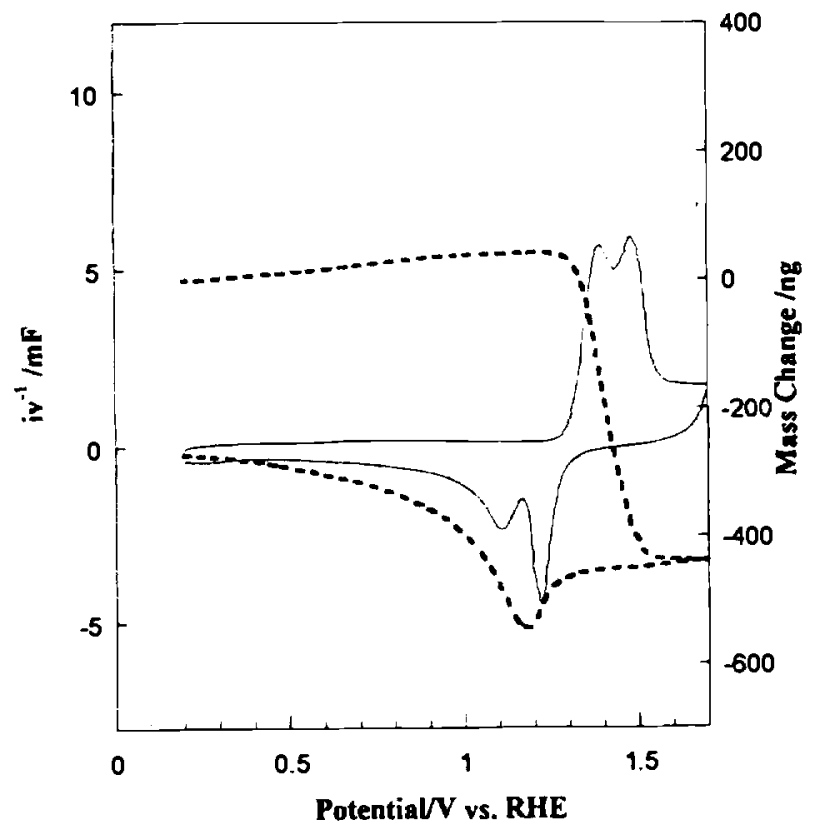

Fig. 4. The potential dependence of currents $(-)$ and mass changes (- - in the potential region between +0.2 and $+1.7 \mathrm{~V}$ in $0.1 \mathrm{M} \mathrm{HClO}_{4}$ solution containing $1 \mathrm{mM} \mathrm{Cl}^{-}$with a sweep rate of (a) 20, (b) 10 , and (c) $5 \mathrm{mV} / \mathrm{s}$. Currents in the figures were divided by sweep rate for normalization to capacitance.
Region I.-As shown in Fig. 3b and 5, a negligible anodic current and a small mass increase were observed in this potential region. This behavior should be associated with the adsorption of $\mathrm{Cl}^{-}$and water molecules on the gold electrode surface which has been previously investigated by several methods, such as electroreflectance, ${ }^{23}$ chronocoulometry, ${ }^{24} \mathrm{EQCM},{ }^{25}$ and radiotracer. ${ }^{26}$

Region II.-As shown in Fig. 7, a good linear relationship was found between the mass decrease and the anodic charge passed in this region. The slope of the straight line gives the mpe in this region as $-66.7 \mathrm{~g} / \mathrm{mol}-\mathrm{e}$. This value is in very good agreement with the one expected for the $3 \mathrm{e}^{-}$ dissolution $(-65.7 \mathrm{~g} / \mathrm{mol}-\mathrm{e})$, clearly demonstrating that the gold electrode dissolves through the $3 \mathrm{e}^{-}$process (reaction 1) in this region.

Region $11 I$.-The straight line relation between the mass change and the anodic charge passed observed in region II

(b)

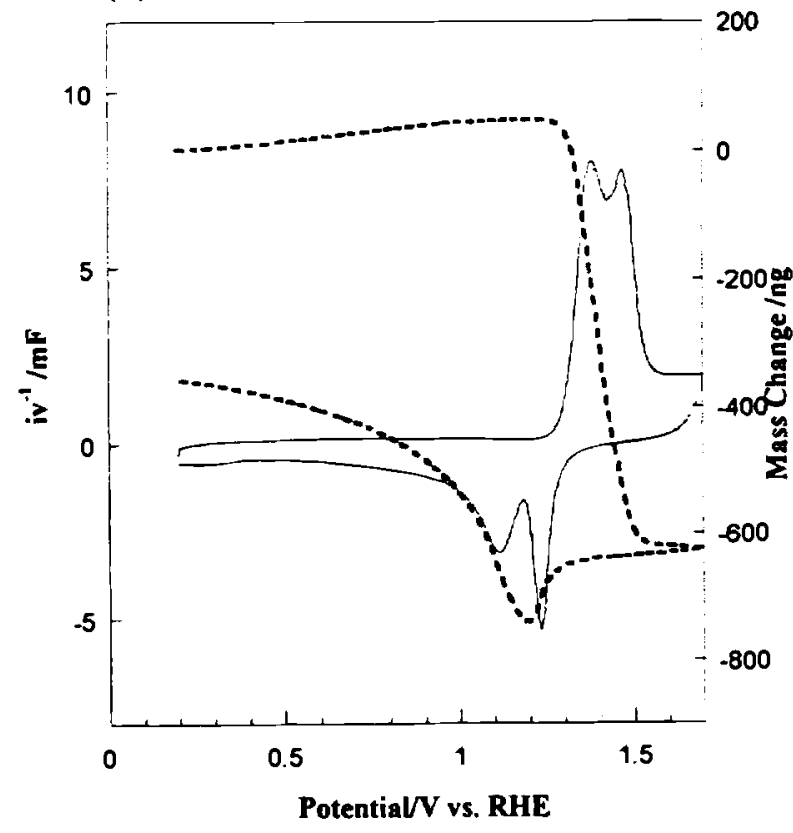

(c)

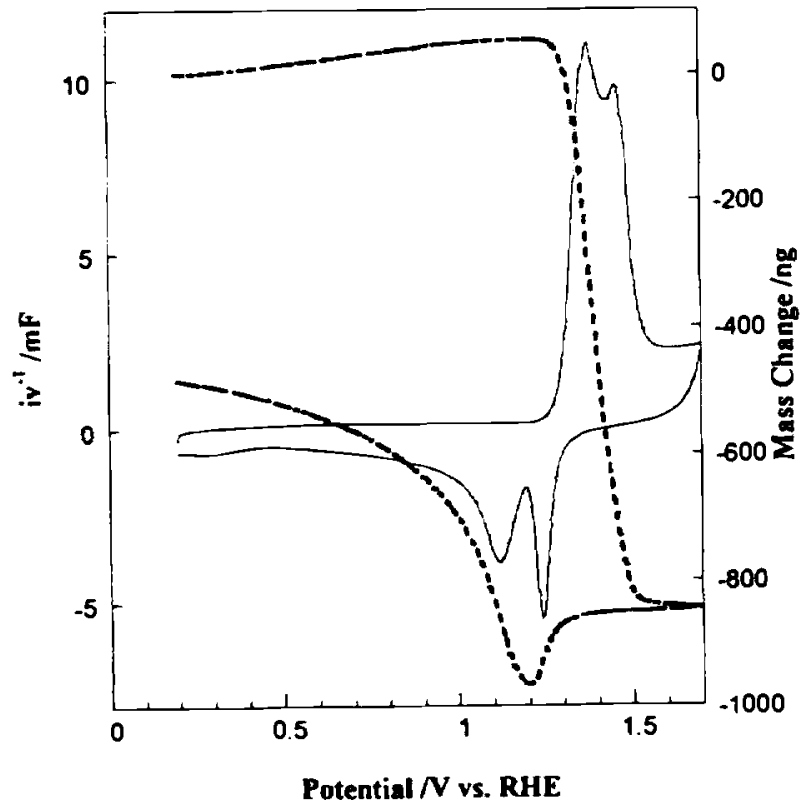




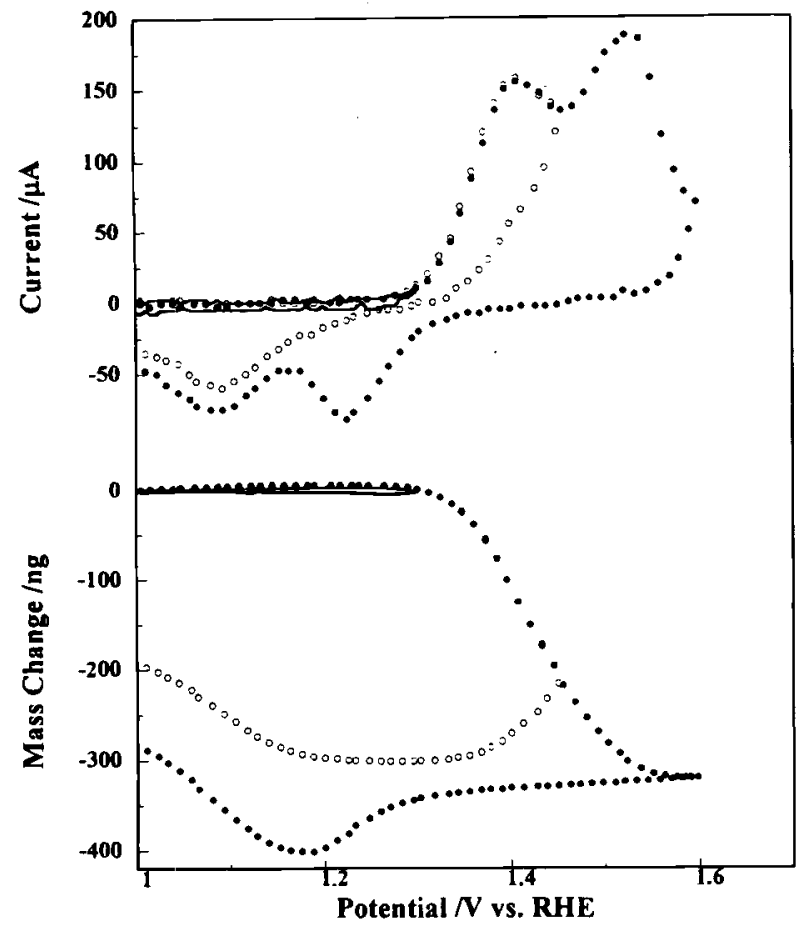

Fig. 5. The potential dependence of current (top) and mass change (bottom) observed during a single potential cycle between $+1.0 \mathrm{~V}$ and various positive potential limits in $0.1 \mathrm{M} \mathrm{HClO}_{4}$ solution containing $1 \mathrm{mM} \mathrm{Cl}^{-}$. Sweep rate $50 \mathrm{mV} / \mathrm{s}$. See text for details.

became a curved line in region III. The tangent line of the curve became smaller as the potential became more positive and finally became nearly zero at the positive potential limit of region III, i.e., the mpe gradually decreased as the potential became positive, suggesting that the mpe is a mixing effect of at least two parallel reactions in the potential region.

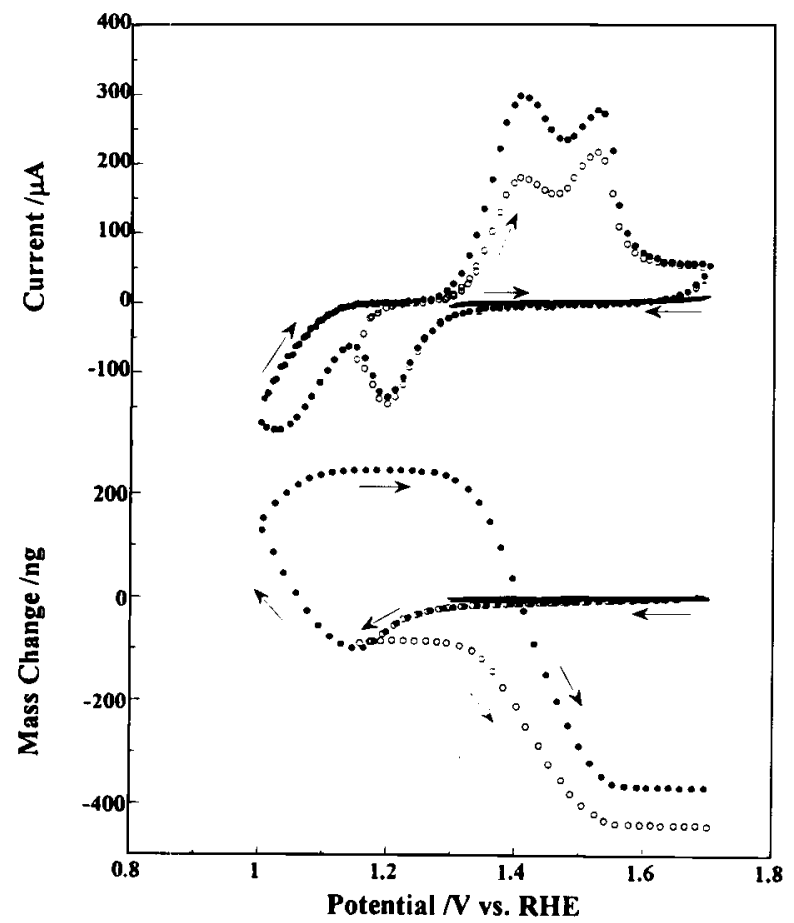

Fig. 6. The potential dependence of current (top) and mass change (bottom) observed during a single potential cycle between $+1.7 \mathrm{~V}$ and various negative polential limits in $0.1 \mathrm{M} \mathrm{HClO}_{4}$ solution containing $1 \mathrm{~m} \mathrm{M} \mathrm{Cl}^{-}$. Scan rate $50 \mathrm{mV} / \mathrm{s}$. See text for details.

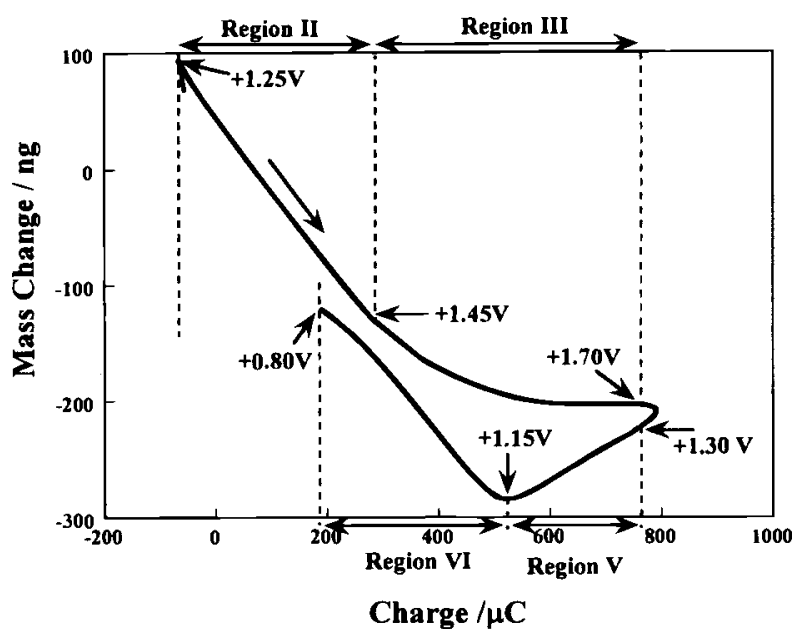

Fig. 7. The relationship belween the mass changes and electric charge passed obtained from Fig. 3b. See text for the division of regions I, II, III, IV, V, and VI.

As described in Fig. 5 and 6, the formation of gold oxide took place in this potential region. The total mpe expected for the formation of gold oxide, $\mathrm{AuOH}$ and $\mathrm{AuO}$, as shown by reactions 4 and 5 , is $+8.0 \mathrm{~g} / \mathrm{mol}-\mathrm{e}$ if additional water and anion adsorption on the oxide is ignored. In fact, the same mpe value of $+8.0 \mathrm{~g} / \mathrm{mol}$-e for the oxide formation process was obtained in a $\mathrm{Cl}^{-}$-free solution (Fig. 3a). Thus, the decrease in the mpe in region III of Fig. 7 should be associated with the oxide formation reaction on the gold surface which gradually inhibits the gold dissolution process (Eq. 1, Eq. 2) and thus, a continuous decrease in the mpe was observed. In order to quantitatively discuss this process, it is necessary to separate the reactions of gold dissolution and oxide formation in this potential region. The total anodic charge $\left(Q^{\mathrm{III}}\right)$ observed in region III is represented as the sum of the anodic charge of the gold dissolution $\left(Q_{\mathrm{d}}^{\mathrm{III}}\right)$ in the same potential region and that of oxide formation in monolayer $\left(Q_{0}\right)$

$$
Q^{\mathrm{III}}=Q_{\mathrm{d}}^{\mathrm{III}}+Q_{0}
$$

where $Q_{0}$ was determined from that of $\mathrm{Cl}^{-}$-free solution (Fig. 3a), i.e., $Q_{0}^{I I I}=345 \mu \mathrm{C}$. The $Q^{\mathrm{III}}$ was directly determined from the anodic charge in region III (Fig. $3 \mathrm{~b}$ ), i.e., $Q^{\mathrm{III}}=498 \mu \mathrm{C}$. Based on Eq. 6, $Q_{d}^{\mathrm{III}}=153 \mu \mathrm{C}$.

The mpe for the gold dissolution in region III can be calculated as follows

$$
\text { mpe }=\frac{\left(\Delta m^{\mathrm{III}}+\Delta m_{0}\right) \times S \times F}{Q_{\mathrm{d}}^{\mathrm{III}} \times 1000}
$$

where $\Delta m^{\mathrm{III}}$ and $\Delta m_{0}$ are the mass changes (ng) observed in region III in $0.1 \mathrm{M} \mathrm{HClO}_{4}$ with $1 \mathrm{mM} \mathrm{Cl}^{-}$(Fig. $3 \mathrm{~b}$ ) and $\mathrm{Cl}^{-}-$ free $\mathrm{HClO}_{4}$ solution in the potential region between +1.1 and $+1.7 \mathrm{~V}$ (Fig. 3a), respectively. $\Delta m^{\mathrm{III}}=-156.3 \mathrm{ng}$ and $\Delta m_{0}=+40.5 \mathrm{ng}$ were obtained from the respective figures. $S$ is the electrode surface area, $S=0.64 \mathrm{~cm}^{2} . F$ is the Faraday constant, $F=96485 \mathrm{C} / \mathrm{mol}$. The mpe for the gold dissolution in region III was $-79.4 \mathrm{~g} /$ mol-e using Eq. 7 . Considering possible overlapping between the reactions in regions II and III and calculation errors in integrating the anodic charge of the respective peaks, this mpe value is in agreement with that expected for the $3 \mathrm{e}^{-}$dissolution process, $-65.7 \mathrm{~g} / \mathrm{mol}-\mathrm{e}$. It demonstrated that the gold surface was partly covered by oxide and is passivated completely when a full monolayer of oxide is formed on the gold surface.

Region IV.-As the potential sweep was reversed at $+1.7 \mathrm{~V}$ in the negative direction, neither current nor mass change was observed until $+1.3 \mathrm{~V}$, suggesting that the gold electrode surface was passivated completely by the oxide formed in region III in the positive sweep (Fig. 3 b and 5). 
Region $V$.-As soon as the cathode current started to flow around $+1.2 \mathrm{~V}$, the surface mass started to decrease (Fig. 3b and 6). A fairly linear relation was obtained between the mass change and the cathodic charge passed with a positive slope from which the mpe was estimated as $+29 \mathrm{~g} / \mathrm{mol}-\mathrm{e}$. The mpe value was higher than that expected for the reduction process of the surface oxide $(+8.0 \mathrm{~g} /$ mol-e). The cathodic charge of the cathodic peak in region IV ( $Q^{\mathrm{IV}}=-299 \mu \mathrm{C}$, Fig. $\left.3 \mathrm{~b}\right)$ was smaller than that required for the reduction of surface oxide on a gold electrode in a $\mathrm{Cl}^{-}$-free solution $\left(Q_{\mathrm{r}}=-366 \mu \mathrm{C}\right.$, Fig. 3a). These results suggest that another anodic reaction should take place simultaneously with the reduction of gold oxide in this potential region. The anodic charge of the additional oxidation reaction $\left(Q_{\mathrm{d}}^{\mathrm{IV}}\right)$ can be estimated using Eq. 8

$$
Q^{\mathrm{IV}}=Q_{\mathrm{d}}^{\mathrm{IV}}+Q_{\mathrm{r}}
$$

as $Q_{\mathrm{d}}^{\mathrm{IV}}=67 \mu \mathrm{C}$. Thus, the mpe for the new reaction can be calculated as follows

(a)

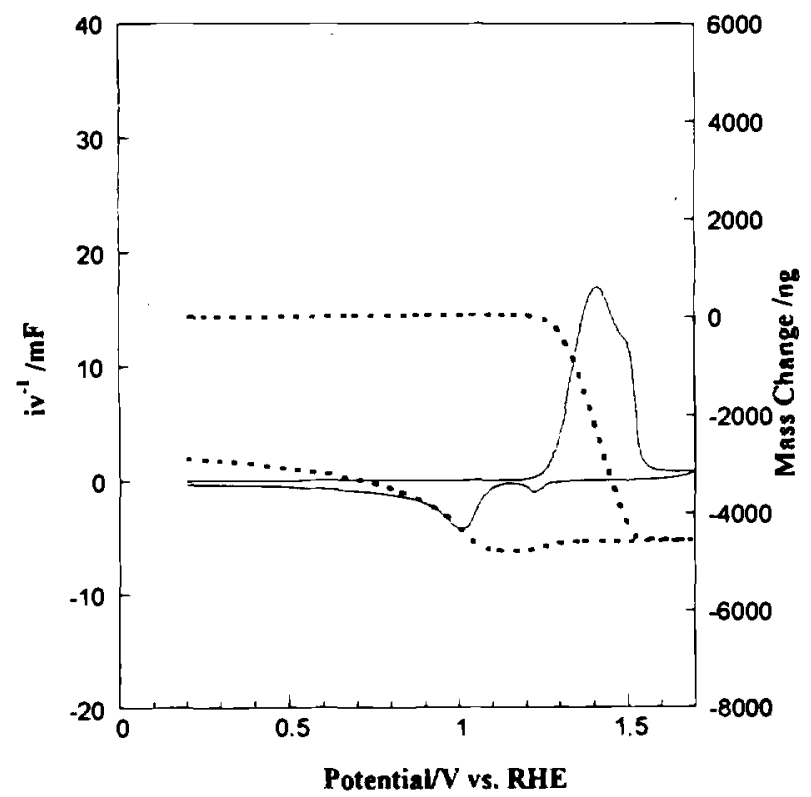

Fig. 8. The potential dependence of currents $\longrightarrow$ and mass changes $(--1$ in the potential region between +0.2 and $+1.7 \mathrm{~V}$ in $0.1 \mathrm{M} \mathrm{HClO}_{4}$ solution containing $10 \mathrm{mM} \mathrm{Cl}^{-}$with a sweep rate of (a) 50, (b) 20 , and (c) $10 \mathrm{mV} / \mathrm{s}$. Currents in the figures were divided by sweep rate for normalization to capacitance.

$$
\text { mpe }=\frac{\left(\Delta m^{\mathrm{IV}}+\Delta m_{\mathrm{r}}\right) \times S \times F}{Q_{\mathrm{d}}^{\mathrm{VV}} \times 1000}
$$

where $\Delta m^{\mathrm{IV}}$ and $\Delta m_{\mathrm{r}}$ are the mass change (ng) observed in $0.1 \mathrm{M} \mathrm{HClO}_{4}$ with $1 \mathrm{mM} \mathrm{Cl}^{-}$in region $\mathrm{V}$ (Fig. 3b) and in $\mathrm{Cl}^{-}$-free $\mathrm{HClO}_{4}$ solution between +1.7 and $+1.0 \mathrm{~V}$ (Fig. $3 \mathrm{a}$ ), respectively. As $\Delta m^{1 \mathrm{v}}=+110.0 \mathrm{ng}$ and $\Delta m_{\mathrm{r}}=-48.2 \mathrm{ng}$, the mpe for the unknown reaction is calculated as -57.0 $\mathrm{g} / \mathrm{mol}-\mathrm{e}$, which is in good agreement with that expected for the $3 \mathrm{e}^{-}$dissolution process $(-65.7 \mathrm{~g} / \mathrm{mol}-\mathrm{e})$. Thus, the "additional anodic reaction" in region IV should be the gold dissolution reaction through a $3 \mathrm{e}^{-}$mechanism (reaction 1) which took place as soon as the surface oxide was reduced.

Region VI.-The surface mass started to increase in region VI and a straight line with a negative slope was again obtained. The mpe was estimated as $-61.8 \mathrm{~g} / \mathrm{mol}-\mathrm{e}$. This value could be clearly explained as the result of a $3 \mathrm{e}^{-}$rede-

(b)

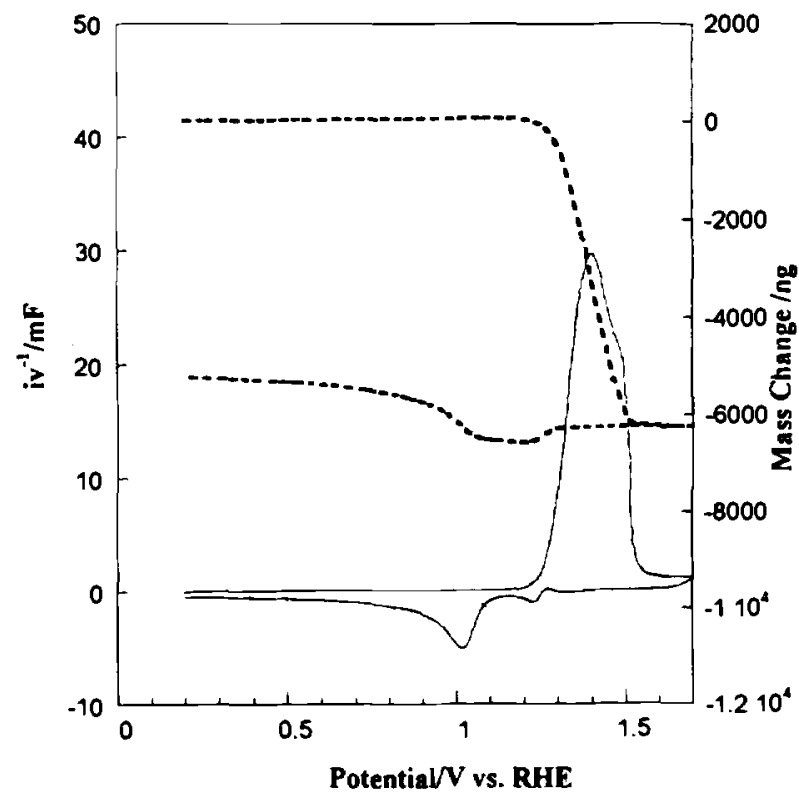

(c)

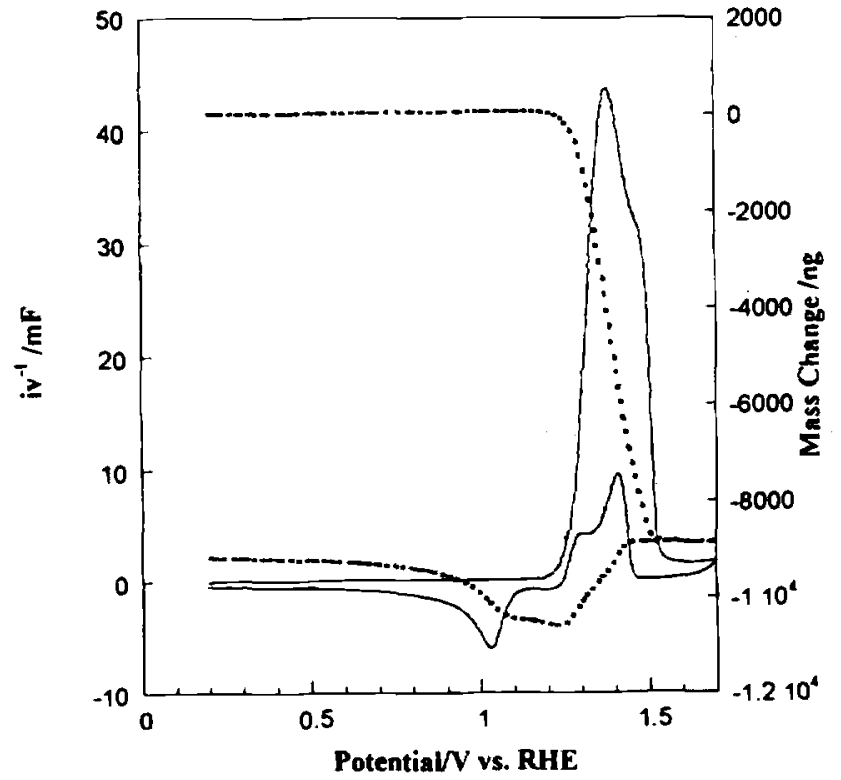


position process of dissolved species $\mathrm{AuCl}_{4}^{-}$(but not $\mathrm{AuCl}_{2}^{-}$) to $\mathrm{Au}$ on the electrode surface, i.e., the reverse reaction of reaction 1 . The redeposition reaction took place when the potential was more negative than $+1.15 \mathrm{~V}$.

Dependence of $\mathrm{Cl}^{-}$concentration.-EQCM measurements were further carried out in $0.1 \mathrm{M} \mathrm{HClO}_{4}$ solution with various concentrations of $\mathrm{Cl}^{-}$. Figure 8 shows the potential dependence of the currents (-) and the mass changes in $0.1 \mathrm{M} \mathrm{HClO}_{4}$ solution containing $10 \mathrm{mM} \mathrm{Cl}^{-}$ with a sweep rate of (a) 50 , (b) 20 , and (c) $10 \mathrm{mV} / \mathrm{s}$. As described previously, the currents were divided by the sweep rate for normalization. The slower the sweep rate, the larger the capacitance and mass changes were observed. The anodic peak in region III was much larger than that observed in a solution containing $1 \mathrm{mM} \mathrm{Cl}^{-}$as shown in Fig. 4 at a given sweep rate. A larger sweep rate dependence was cbserved, especially in region $\mathrm{V}$ in the negative potential sweep. When the sweep rate was high $(50 \mathrm{mV} / \mathrm{s})$, a small cathodic peak was observed at $+1.22 \mathrm{~V}$, which was very small compared to that of the second cathodic peak at $+1.0 \mathrm{~V}$ (Fig. 8a). As the sweep rate was lowered to $20 \mathrm{mV} / \mathrm{s}$, in addition so the small cathodic peak at $+1.22 \mathrm{~V}$, an anodic peak was observed at $+1.27 \mathrm{~V}$ as a pair of bipolar redox peaks (Fig. 8b). Similar changes were also observed in the $\mathrm{CV}$ of $100 \mathrm{mM} \mathrm{Cl}^{-}$solution with a higher sweep rate $(50 \mathrm{mV} / \mathrm{s}$, Fig. 1f). When the sweep rate was further reduced to $10 \mathrm{mV} / \mathrm{s}$, a broad anodic peak was observed at $+1.43 \mathrm{~V}$ with a shoulder at $+1.3 \mathrm{~V}$, and no cathodic peak was observed in this region (Fig. 8c). A large surface mass decrease was observed from $+1.4 \mathrm{~V}$, corresponding well to this anodic current flow (Fig. 8c). Since the potential for this anodic peak was more positive than that for the reduction of gold oxide in $\mathrm{Cl}^{-}$-free solution (Fig. 3a), the gold oxide seems to be unstable and can be partly destroyed by a concentrated $\mathrm{Cl}^{-}$solution, especially under the condition of lower sweep rate. The second cathodic peak around $+1.08 \mathrm{~V}$ in region VI, however, did not change much with the sweep rate. These results confirmed the conclusion described previously (Fig. 7), i.e., dissolution of gold took place as soon as the gold oxide formed in region III was reduced.

Quantitative analyses described in the previous section were employed for the $0.1 \mathrm{M} \mathrm{HClO}_{4}$ with various concentrations of $\mathrm{Cl}^{-}$. Although the CVs and the mass changes depended on the $\mathrm{Cl}^{-}$concentration, similar potential regions as already described were used for these solutions. Table I summarizes the mpe values as a function of the $\mathrm{Cl}^{-}$concentration in the respective potential regions. The potential limits for the respective regions are given in the same table.

As shown in Table I, the mpe values in regions II and VI in the solutions with different concentrations of $\mathrm{Cl}^{-}$were found to be between -50 and $-70 \mathrm{~g} / \mathrm{mol}-\mathrm{e}$. As discussed in the case of the $0.1 \mathrm{M} \mathrm{HClO}_{4}$ solution with $1 \mathrm{mM} \mathrm{Cl}^{-}$, the processes in region II and region VI corresponded to the $3 \mathrm{e}^{-}$dissolution and $3 \mathrm{e}^{-}$redeposition processes on the gold electrode, respectively. Considering a possible incomplete separation of respective regions and calculation errors in integrating the respective peak areas, it is fair to say that these values were in good agreement with the mpe values
$(-65.7 \mathrm{~g} / \mathrm{mol}-\mathrm{e})$ expected for the $3 \mathrm{e}^{-}$dissolution of gold (reaction 1) or $3 \mathrm{e}^{-}$redeposition of $\mathrm{AuCl}_{4}^{-}$species (reverse reaction of reaction 1 ).

No evidence was found in the EQCM measurements for the $1 \mathrm{e}^{-}$redeposition (reaction 2 ) for which the mpe is expected to be $-197 \mathrm{~g} / \mathrm{mol}-\mathrm{e}$.

The mpe values of regions III and V (Table I) were obtained after subtracting the effects of oxide formation or reduction reactions on a gold electrode surface by using the same procedures described in the previous section. Again, these values are close to the mpe value expected for the $3 \mathrm{e}^{-}$ dissolution process (reaction 1), i.e., the formation of gold oxide was started in region III as a competition reaction for gold dissolution, and the dissolution was completely inhibited when a full monolayer oxide was formed on the gold electrode surface in region IV.

EQCM characterization with potentiostatic measurement.-The current and the mass change during the gold dissolution process were further investigated using the potentiostatic measurements.

Figure 9a shows a typical result for the potentiostatic measurement in which the current and the mass change were recorded simultaneously as a function of time in $0.1 \mathrm{M} \mathrm{HClO}_{4}$ solution containing $5 \mathrm{mM} \mathrm{Cl}^{-}$when the potential was stepped from +1.0 to $+1.3 \mathrm{~V}$ in region II where the gold was dissolved. A large anodic current spike due to the charging of the double layer flowed immediately after the potential step, after which the anodic current quickly decreased and reached a steady current of $5 \mu \mathrm{A}$. The surface mass started to decrease as soon as potential was stepped to $+1.3 \mathrm{~V}$. A good linear relationship was obtained between the mass decrease and the anodic charge passed (Fig. 9b). The mpe was calculated from the slope of the straight line as $-64.7 \mathrm{~g} / \mathrm{mol}-\mathrm{e}$. This value is in good agreement with the value expected for the $3 \mathrm{e}^{-}$gold dissolution process $(-65.7 \mathrm{~g} / \mathrm{mol}-\mathrm{e}$, reaction 1$)$, confirming that a $3 \mathrm{e}^{-}$ dissolution process for the gold electrode took place under the present potentiostatic conditions.

Figure 10 summarizes the potential dependence of the anodic current (Fig. 10a) and the mpe (Fig. 10b) obtained by the potentiostatic measurements in $0.1 \mathrm{M} \mathrm{HClO}_{4}$ solution containing $5 \mathrm{mM} \mathrm{Cl}^{-}$. In Fig. 10a, a linear relationship was observed between +1.2 and $+1.3 \mathrm{~V}$ and the Tafel slope of the straight line was ca. $0.054 \mathrm{~V}$, which is the same as those reported previously. ${ }^{4,8,9,11}$ The anodic current was found to be independent of the potential in the more positive potential region between +1.35 and $+1.50 \mathrm{~V}$. It is evident that this is associated with the diffusion-controlled dissolution process which has been well studied by rotating disk electrode..$^{5,8,9,11}$ As the potential entered region III, the steady anodic current started to decrease. This should be attributed to the formation of oxide on the gold electrode surface as previously mentioned

Figure $10 \mathrm{~b}$ shows the potential dependence of the mpe determined by the potentiostatic measurement in regions II and III. In region II, the mpe was nearly constant and was close to the value of $-65.7 \mathrm{~g} / \mathrm{mol}$-e (indicated by the dotted line) which is expected for the $3 \mathrm{e}^{-}$dissolution process of the gold electrode. As the potential became more positive than

Table I. $\mathrm{Cl}^{-}$concentration dependence of the mpe observed in regions II, III, V, and VI.

\begin{tabular}{|c|c|c|c|c|}
\hline $\begin{array}{l}\text { Concentration } \\
\text { (mM) }\end{array}$ & $\begin{array}{l}\text { mpe (g/mol-e) } \\
\text { in region II }\end{array}$ & $\begin{array}{l}\text { mpe (g/mol-e) } \\
\text { in region III }\end{array}$ & $\begin{array}{l}\text { mpe }(\mathrm{g} / \mathrm{mol}-\mathrm{e}) \\
\text { in region } \mathrm{V}\end{array}$ & $\underset{\text { in region VI }}{\mathrm{mpe}(\mathrm{g} / \mathrm{mol}-\mathrm{e})}$ \\
\hline 0.1 & $\begin{array}{c}-59.8 \\
(1.33-1.45 \mathrm{~V})\end{array}$ & $\begin{array}{c}-78.2 \\
(1.45-1.70 \mathrm{~V})\end{array}$ & $\begin{array}{c}-55.2 \\
(1.30-1.16 \mathrm{~V})\end{array}$ & $\begin{array}{c}-48.4 \\
(1.16 \mathrm{~V} \sim)\end{array}$ \\
\hline 1 & $\begin{array}{c}-66.7 \\
(1.25-1.45 \mathrm{~V})\end{array}$ & $\begin{array}{c}-79.4 \\
(1.45-1.70 \mathrm{~V})\end{array}$ & $\begin{array}{c}-57.0 \\
(1.30-1.15 \mathrm{~V})\end{array}$ & $\begin{array}{c}-61.8 \\
(1.15 \mathrm{~V} \sim)\end{array}$ \\
\hline 2 & $\begin{array}{c}-65.0 \\
(1.25-1.47 \mathrm{~V})\end{array}$ & $\begin{array}{c}-60.4 \\
(1.47-1.70 \mathrm{~V})\end{array}$ & $\begin{array}{c}-62.6 \\
(1.30-1.14 \mathrm{~V})\end{array}$ & $\begin{array}{c}-66.6 \\
(1.14 \mathrm{~V} \sim)\end{array}$ \\
\hline 5 & $\begin{array}{c}-61.8 \\
(1.25-1.49 \mathrm{~V})\end{array}$ & $\begin{array}{c}-64.8 \\
(1.49-1.70 \mathrm{~V})\end{array}$ & $\begin{array}{c}-68.3 \\
(1.40-1.14 \mathrm{~V})\end{array}$ & $\begin{array}{c}-66.5 \\
(1.14 \mathrm{~V} \sim)\end{array}$ \\
\hline 10 & $\begin{array}{c}-58.9 \\
(1.22-1.51 \mathrm{~V})\end{array}$ & $\begin{array}{c}-51.6 \\
(1.51-1.70 \mathrm{~V})\end{array}$ & $\begin{array}{c}-66.8 \\
(1.40-1.15 \mathrm{~V})\end{array}$ & $\begin{array}{c}-64.2 \\
(1.15 \mathrm{~V} \sim)\end{array}$ \\
\hline
\end{tabular}




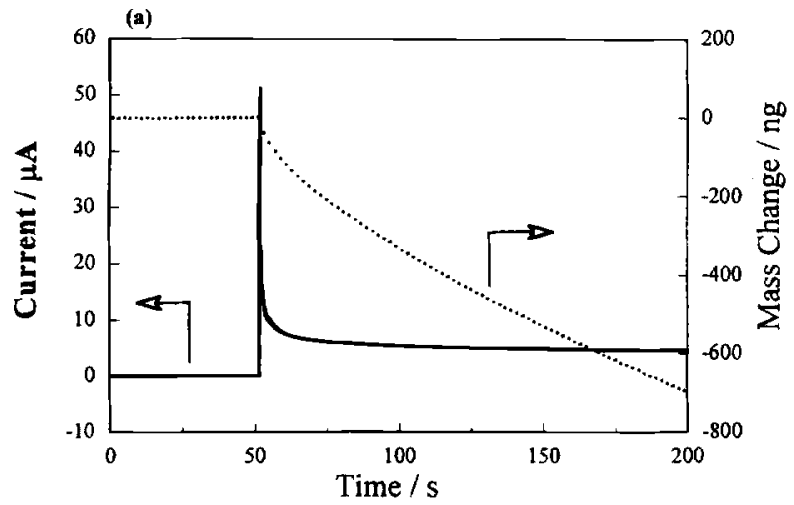

(b)

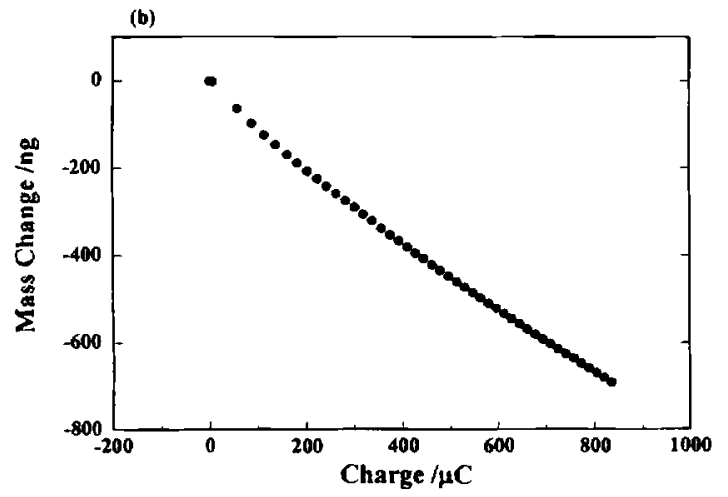

Fig. 9. (a) The time dependence of the current and the mass change simultaneously recorded as the potential was stepped from +1.0 to $+1.3 \mathrm{~V}$. (b) The relationship between the mass change and the anodic charge as the potential was stepped from +1.0 to $+1.3 \mathrm{~V}$ in $0.1 \mathrm{M} \mathrm{HClO}_{4}$ solution containing $5 \mathrm{mM} \mathrm{Cl}^{-}$.
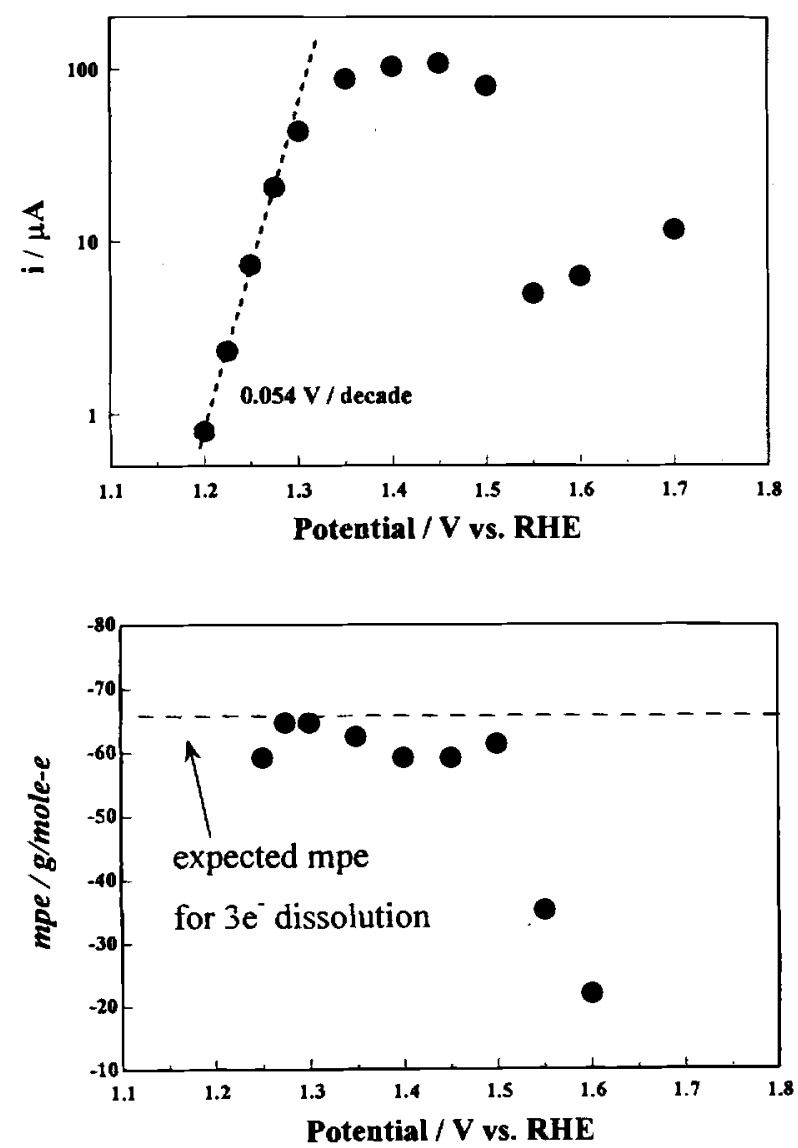

Fig. 10. The potential dependence of (a, top) anodic current and (b, bottom) mpe obtained by the potentiostatic polarization measurements in $0.1 \mathrm{M} \mathrm{HClO}_{4}$ solution containing $5 \mathrm{mM} \mathrm{Cl}^{-}$.
$+1.5 \mathrm{~V}$ (region III), the observed mpe started to decrease. The mpe was found to be ca. $-20 \mathrm{~g} / \mathrm{mol}-\mathrm{e}$ at $+1.6 \mathrm{~V}$. As discussed in the case of the potential sweep in the same potential region, this decrease should be related to the formation of a surface oxide which inhibits further gold dissolution.

In both the potential sweep and potentiostatic measurements, only the $3 \mathrm{e}^{-}$dissolution/redeposition was observed. This conclusion is different from those reported before in which a $1 \mathrm{e}^{-}$dissolution process was also found..$^{4,-9,11}$ Many reasons are considered in order to explain this difference. One of the important reasons is the different sensitivity and accuracy between the present EQCM measurement and experimental methods used in the previous studies. In the previous studies, usually a long electrolysis time was necessary to obtain enough sensitivity in the subsequent product analyses. A significant change in the surface state on the gold electrode may take place and large errors in the quantitative analyses may be introduced during prolonged electrolysis. The in situ EQCM measurement should be much more reliable as it can detect the absolute mass change with the highest mass precision (several percent of a monolayer) and a very short electrolysis time (less than a few seconds) is required.

$\mathrm{Cl}^{-}$concentration-dependent potential region for dissolution and passivation.-Figure 11 summarizes the $\mathrm{Cl}^{-}$concentration $(0.1-10 \mathrm{mM})$ dependent potential regions in which the potential boundaries between regions I, II, and III were obtained by EQCM measurement with potential sweep. Since the concentration of $\mathrm{AuCl}_{4}^{-}$was unknown in the present experiment, the equilibrium potential of $\mathrm{AuCl}_{4}^{-} / \mathrm{Au}$ was estimated as a function of the $\mathrm{Cl}^{-}$concentrations by the Nernst equation for $\mathrm{AuCl}_{4}^{-}$concentrations from 0.001 to $10 \mathrm{mM}$ (Fig. 12). However, the calculated equilibrium potentials were more negative than the onset potentials observed even for the case of $2.5 \mathrm{mM} \mathrm{AuCl}_{4}^{-}$-containing solution, which is the highest available $\mathrm{AuCl}_{4}^{-}$concentration for the solution containing $10 \mathrm{mM} \mathrm{Cl}^{-}$. This difference between the experimentally observed onset potential and the calculated equilibrium potential should be caused by the adsorption of $\mathrm{Cl}^{-}$on the $\mathrm{Au}(111)$ electrode ${ }^{6,23-26}$

As shown in Fig. 11, the gold electrode started to dissolve at a less positive potential when the $\mathrm{Cl}^{-}$concentration increased. The equilibrium potential for the $3 \mathrm{e}^{-}$dissolution reaction of the gold electrode (reaction 1) is expected to linearly decrease with the logarithmic concentration of $\mathrm{Cl}^{-}$with a slope of $-(0.060 / 3) \times 4=-0.080 \mathrm{~V} /$ dec from the Nernst equation if the concentration of $\mathrm{AuCl}_{4}^{-}$ is constant. It was found from Fig. 12 that the onset potential for gold dissolution linearly shifted to a negative direction with the logarithmic concentration of $\mathrm{Cl}^{-}$with a slope of ca. $-0.054 \mathrm{~V} / \mathrm{dec}$, lower than the expected one $(-0.080 \mathrm{~V} / \mathrm{dec})$. This may also be related to the specific adsorption of $\mathrm{Cl}^{-}$on the $\mathrm{Au}(111)$ electrode.

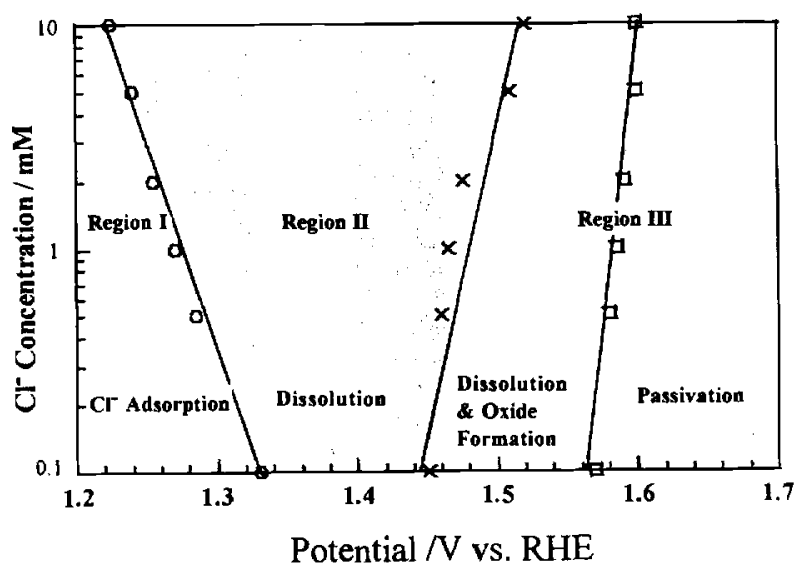

Fig. $11 . \mathrm{Cl}^{-}$concentration-dependent polential region in positive-going sweep in $0.1 \mathrm{M} \mathrm{HClO}_{4}$ solution contoining $\mathrm{Cl}^{-}$. 


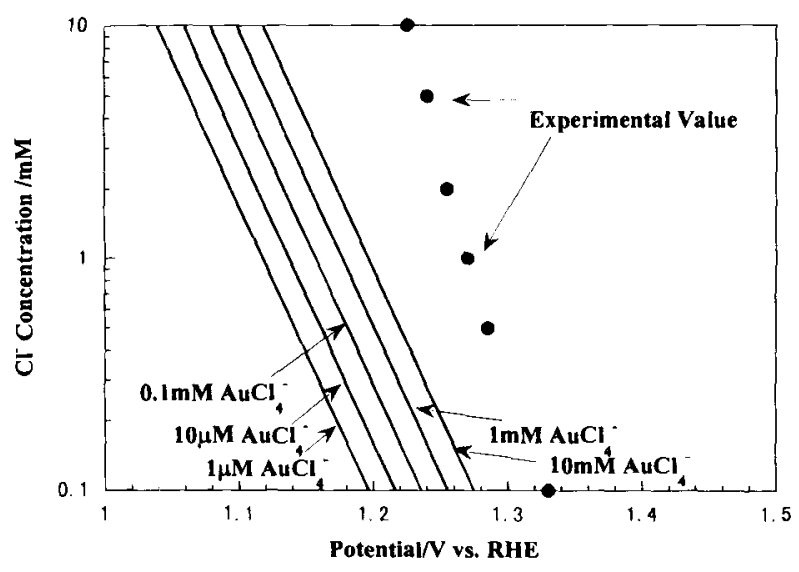

Fig. 12. The equilibrium potential of $\mathrm{AuCl}_{4}^{-} / \mathrm{Au}$ estimafed by Nernst equation as a function of the $\mathrm{Cl}^{-}$concenfration for concentrations of $\mathrm{AuCl}_{4}^{-}$from $1 \mu \mathrm{M}$ to $10 \mathrm{mM}$, shown by the arrows in the figure.

The onset potential for the oxide formation depended on the $\mathrm{Cl}^{-}$concentration. The higher the $\mathrm{Cl}^{-}$concentration, the more positive the onset potential. A similar tendency was found for the onset potential of the passive region. This passive oxide layer, however, is unstable and is partly destroyed in a concentrated $\mathrm{Cl}^{-}$-containing $\mathrm{HClO}_{4}$ solution.

An in situ EC-STM study is now underway to investigate in detail the dissolution and redeposition processes on an $\mathrm{Au}(111$; electrode surface.

\section{Conclusion}

The dissolution process of the gold electrode in $\mathrm{HClO}_{4}$ solution containing various concentrations of $\mathrm{Cl}^{-}$was investigated by in situ EQCM measurements. The EQCM results clearly demonstrate that gold dissolves through a $3 \mathrm{e}$ oxidation process in the anodic potential region. No evidence for the $1 \mathrm{e}^{-}$dissolution was obtained in the present study.

\section{Acknowledgment}

This work was partially supported by a Grant-in-Aid for Scient:fic Research on Priority Area of "Electrochemistry of Ordered Interfaces" (No. 09237101) from the Ministry of Education, Science, Sports, and Culture, Japan.

Manuscript submitted August 27, 1997; revised manuscript received February 6, 1998.

Hokkaido University assisted in meeting the publication costs of this article.

\section{REFERENCES}

1. G. M. Schmid and M. E. Curley-Fiorino, in Encyclopedia of Electrochemistry of the Elements IV, A. J. Bard, Editor, Marcel Dekker, Inc., New York (1975).
2. D. W. Kirk, F. R. Foulkes, and W. F. Graydon, J. Electrochem. Soc., 127, 1069 (1980)

3. G. H. Kelsall, N. J. Welham, and M. A. Diaz, J. Electroanal. Chem., 361, 13 (1993).

4. T. Heumann and H. S. Panesar, Z. Phys. Chem., 229, 84 (1965).

5. J. N. Gauer and G. M. Schmid, J. Electroanal. Chem., 24, 279 (1970).

6. S. H. Cadle and S. Bruckenstein, J. Electroanal. Chem., 48, 325 (1973).

7. R. P. Frankenthal and D. E. Thompson, J. Electrochem. Soc., 123, 799 (1976).

8. R. P. Frankenthal and D. J. Siconolfi, J. Electrochem. Soc., 129, 1192 (1982).

9. T. Horikoshi, S. Yoshimura, N. Kubota, and E. Sato, Nippon Kagakukaishi, 1118 (1983).

10. B. Lovrecek, K. Moslavac, and D. Matic, Electrochim. Acta, 26, 1087 (1981).

11. M. A. Diaz, G. H. Kelsall, and N. J. Welham, J. Electroanal. Chem., 361, 25 (1993).

12. B. H. Loo, J. Phys. Chem., 86, 433 (1982).

13. D. J. Trevor, C. E. D. Chidsey, and D. N. Loiacono, Phys. Rev. Lett., 62, 929 (1989).

14. H. Honbo, S. Sugawara, and K. Itaya, Anal. Chem., 62, $2424(1990)$

15. G. Sauerbrey, Z. Phys., 155, 206 (1959).

16. S. Bruckenstein and M. Shay, Electrochim. Acta, 30, 1295 (1985).

17. D. A. Buttry and M. D. Ward, Chem. Rev., 92, 1355 (1992).

18. K. Shimazu, I. Yagi, Y. Sato, and K. Uosaki, Langmuir, 8, 1385 (1992).

19. M. S. Zei, Y. Nakai, G. Lehmpfuhl, and D. M. Kolb, J. Electroanal. Chem., 150,201 (1983)

20. K. Uosaki, S. Ye, and T. Kondo, J. Phys. Chem., 99, 14117 (1995).

21. J. Clavilier, R. Faure, G. Guinet, and R. Durand, J. Electroanal. Chem., 107, 205 (1980).

22. K. Uosaki, S. Ye, Y. Oda, T. Haba, and K. Hamada, Langmuir, 13, 594 (1997)

23. T. Takamura, K. Takamura, and E. Yeager, J. Electroanal. Chem., 29, (1971).

24. Z. Shi and J. Lipkowski, J. Electroanal. Chem., 403, $225(1996)$.

25. H. W. Lei, H. Uchida, and M. Watanabe, Langmuir, 13, 3523 (1997).

26. A. Kolics, A. E. Thomas, and A. Wieckowski, J. Chem. Soc., Faraday Trans., 92, 3727 (1996).

27. H. Angerstein-Kozlowska, B, E. Conway, A. Hamelin, and L. Stoicoviciu, Electrochim. Acta, 31, 1051 (1986).

28. H. Angerstein-Kozlowska, B. E. Conway, A. Hamelin, and L. Stoicoviciu, J. Electroanal. Chem., 228, 429 (1987).

29. S. Bruckenstein and M. Shay, J. Electroanal. Chem., 188, 131 (1985).

30. W. Stockel and R. Schumacher, Ber. Bunsen-Ges. Phys. Chem., 91, 345 (1987).

31. J. S. Godon and D. C. Johnson, J. Electroanal. Chem., 365, 267 (1994).

32. C. M. Vitus and A. J. Davenport, J. Electrochem. Soc., 141, 1291 (1994). 